\title{
European Influences: Edwin Muir, Kafka, and the Spirit of Italy
}

\author{
Margery Palmer MCCULLOCH \\ University of Glasgow, UK \\ School of Critical Studies \\ Margery.PalmerMcCulloch@glasgow.ac.uk
}

\begin{abstract}
Starting from Orkney-born Edwin Muir's article "North and South," published in the American Freeman magazine in 1922, this essay will explore Muir's involvement with the life and thought of Europe throughout his life and his work as poet, novelist, translator, and critic; and his particular fascination with what he saw as the philosophical difference between the European peoples of the north and the south in relation to their contrasting perceptions of Time and the idea of Fate in human lives. The essay will discuss Muir's relationship with the work of Franz Kafka, whose novels Muir and his wife Willa were the first to translate into English, and the effect of this relationship with Kafka and the city of Prague on his own poetry. It will also explore the contrasting southern influence of Italy, and the city of Rome where Muir went as Director of the British Council Institute in 1949. The paper will conclude with a consideration of what it is in Muir's poetry and thought which marks him out as the European modernist poet the later Seamus Heaney considered him to be, and which also makes him a poet of continuing relevance to our own times.
\end{abstract}

Keywords: Edwin Muir, Franz Kafka, Scotland, Europe, modernism

In his article "North and South," published in the American Freeman magazine in November 1922, the poet and critic Edwin Muir considered what seemed to him to be the philosophical difference between the peoples of northern and southern Europe, their contrasting perceptions of Time, and of the idea of Fate in human lives. He wrote that "since the rebirth of culture during the Renaissance there has always been in Northern Europe a poignant longing for the South as for a home from which men were exiled and to which they could never return" (Muir 1924: 103). In Muir's interpretation, this longing was felt "as a sense of mystery and of loss as strong as that which religious men feel when they dream of a lost Paradise, as hopeless as that which poets cherish for their vanished childhood." And he believed that the supreme expression in poetry of this "vast regret," this Sehnsucht, was to be found in Mignon's song from Goethe's Wilhelm Meister, "Kennst du das Land." Muir added that "Heine in his lyric, 'Ein Fichtenbaum Steht Einsam,' knew that in writing about it 
enigmatically, in mere hints, he would be understood by Northern people; so universal and so inescapable was this emotion" (Muir 1924: 103-04).

At the present time, Edwin Muir is a somewhat marginalized figure in the narrative of Anglophone modernism, partly, I would suggest, because as poet he came to maturity in the 1940s and 1950s as opposed to the earlier immediate post-World War One period of contemporaries such as T. S. Eliot and Hugh MacDiarmid. In addition, Muir's reputation in contemporary Scottish academic circles appears to rest neither on his poetry nor on his bringing Scotland and Europe into contact with each through his European writings, but principally on his quarrel with fellow poet MacDiarmid over his statement in the 1936 prose book Scott and Scotland that ambitious Scottish poets should use the English language as opposed to Scots in their writing. ${ }^{1}$ In contrast, when the wider situation of new writing in Britain in the post1918 phase of literary modernism is considered, one finds that Muir was a prominent participant in the literary debates of his time. His first book We Moderns, published under the pseudonym of Edward Moore in 1918, had initially appeared as a series of articles in The New Age, an influential London-based magazine edited by A. R. Orage to which Muir was a regular contributor. The success of We Moderns led to an American edition in 1920, introduced by H. L. Mencken; and the book's continuing success in the USA earned Muir a contract with the American Freeman magazine which allowed him and his wife Willa to travel in Europe, thus bringing first-hand living experience to a continent known previously only through its literature. Muir contributed his impressions of the places they visited to the Freeman, and this European sojourn also gave both Muirs the opportunity to learn German and so begin the translation of German-language writers which provided a large part of their income until the outbreak of World War Two in 1939. This translation of Germanlanguage literature included the first translations into English of the works of the Czech German-language modernist Franz Kafka. On his return from that first period of travel in Europe, Muir became a regular contributor to the principal London periodicals of the time, and also published the first English-language essay on the German poet Friedrich Hölderlin. His own First Poems, published by Virginia and Leonard Woolf at the Hogarth Press in 1925, were written largely as a result of his early European experiences, as was his first novel The Marionette (1927), set in Salzburg. Europe was therefore a significant actual presence in Edwin Muir's life from the early 1920s, and the continent and its literature and culture continued to be an influence on his work throughout his life.

This discussion of Edwin Muir and Europe began with a reference to the distinction he made between the peoples of northern and southern Europe in his

\footnotetext{
${ }^{1}$ The continuance of this disagreement, however, was largely on MacDiarmid's side, as Muir made it clear in a subsequent series of articles in the Bulletin newspaper (reproduced in Scottish Studies Review 6.1 , Spring $2005,59-73$ ) that he was attempting to start a debate about language use, not set language rules in concrete.
} 
Freeman article "North and South," and this philosophical opposition is something found also in his own creative writing. His reference to the longing or Sehnsucht that he found in Goethe's "Mignon's Song," and his description of this as "a sense of mystery and of loss as strong as that which religious men feel when they dream of a lost Paradise, as hopeless as that which poets cherish for their vanished childhood" (Muir 1924: 103) is particularly relevant to much of his own early poetry in First Poems; while the metaphor of the biblical Fall and the expulsion from the Garden of Eden is a recurring motif throughout his work, early and late. Edwin Muir's childhood was spent on the small Orkney island of Wyre where his father had a farm, but lack of money to take advantage of the changes taking place in farming at the end of the nineteenth century forced the family into emigration to the Scottish mainland and the industrialized city of Glasgow - in many ways "another country" for the Muirs. Within five years of their arrival in Glasgow both parents and two brothers had died and Muir himself was left at the age of eighteen to fend for himself in an alien environment. His comparison about Romantic period longing being like the hopeless dream that poets cherish for their vanished childhood was therefore for him no mere literary trope but a simile that derived directly from his own experience. ${ }^{2}$ In this respect, it is interesting to contrast Muir's imagery in these early "lost land" poems from his First Poems collection with that of Goethe's "Kennst du das Land" which he so much admired. Goethe's Mignon may have lost her childhood home but it remains vital in her memory: "die Zitronen blühn,/Im dunkeln Laub die Goldorangen glühn"; "Es glänzt der Saal, es schimmert das Gemach" (Closs 1957: 219-220) - everything in this description is glowing with colour, shimmering with light. Muir's lost childhood land, however, is uncertain, unreliable in its dream images: "The houses waver towards me, melt and run"; "Alas! I do not know/This place, and alien people come and go" (Muir 1991: 4). Biblical imagery, including imagery of "The Fall," is a recurring presence in Muir's poetry as a whole. However, in contrast to the early uncertainty in relation to lost lands and an anxiety to find a way to annul or redeem this loss, to "hang the apple on the tree" (Muir 1991: 80), in his mature poetry of the 1940 s and 1950s he is able to use biblical imagery, and especially the lost Eden imagery, in a more sophisticated metaphorical manner. Bringing past time into creative interaction with the present continued to be a philosophical preoccupation in Muir's writing, but it was his travel in Europe in the early 1920s, where he said he experienced the first real leisure and time to think that he had had since he was fourteen, that enabled him to begin the process of recovering his own lost past, thus allowing it to be a living part also of his present.

\footnotetext{
${ }^{2}$ In her poem "Originally" from The Other Country (1990), the poet Carol Ann Duffy - Scottishborn but currently the British poet-laureate - has described all childhood experience as "an emigration," and she, like Muir, experienced the particularly difficult actual emigration from her childhood home in Scotland to a new and initially strange life in another country, England. Many of her early poems draw on this experience of loss and alienation.
} 
In the 1930s, Muir's prose-writing - criticism, travel-writing, fiction and translation - continued to take publication precedence over his poetry output; and his wife Willa and he received special acclaim as the first translators into English of the German-language work of the Czech modernist writer Franz Kafka and the Austrian Hermann Broch. In our own time, Willa Muir is increasingly recognized by scholars working in this area as having been the principal translator - in relation to linguistic competence and the amount of time spent on the translation work. Such a perception is supported by various comments in the Muirs' correspondence from this period in their lives, although Edwin's contribution was clearly significant in relation to his creative response to and involvement with the works translated. Muir himself wrote to a friend in the late 1920s, shortly after his discovery of Kafka's Das Schloss, that they were translating it for the publisher Secker, and that it was "a purely metaphysical and mystical dramatic novel $[\ldots]$ and yet in a curious way everything is given solidly and concretely." He added: "it appeals particularly to the part of me which wrote The Marionette" (Muir 1974: 67), (which was Muir's own "metaphysical and mystical" yet "concrete" dramatic novel - an interesting short book, set in Salzburg, about an autistic boy who is enabled to reconnect with the world about him through his involvement with a puppet theatre). Clearly Edwin Muir had felt a philosophical and creative affinity with Kafka's work from his very first reading of Das Schloss; and one can see how this book could relate in his mind to that earlier distinction he had made in his Freeman essay between the philosophical responses of the European peoples of the North and South. In a chapter on "The Metaphysics of Modernism" in the Cambridge Companion to Modernism, the writer Michael Bell comments that "the anguish in Kafka's fiction, whatever its other causes or implications, comes from a desire still to find, rather than create, a meaning" (1999: 14). This view of Kafka seems applicable also to Edwin Muir, whose poetry, both mature and earlier immature, points towards the belief that there is a meaning to be sought for in human life, despite what might seem to be indications towards the contrary. Similarly, as he discussed in his Freeman "North and South" article, he believed in what he called "a northern conception of freedom, as emancipation" (Muir 1924: 111), a view recognisable in his life-long arguments in poetry and prose against Scottish Calvinism and its concept of a predetermined fate in human lives; something he equated also with Russian Bolshevism as can be seen in his article "Bolshevism and Calvinism," published in 1934 in the European Quarterly, the journal he founded and co-edited with Janko Lavrin.

Both Muirs had felt a particular affinity with the city of Prague, recommended to them by Lavrin, and the first European city they stayed in during their European travels of the early 1920s. However, mostly for difficulty of language reasons, they did not sense the undercurrents in Czech society during that early period of a new Czech independence. Nor did they realise that there were divisions in the city between the vibrant new artistic and theatrical activities of the Čapek brothers, Karl and Josef, to whom they had been given letters of introduction, and the German-language and 
Jewish inhabitants of the city, of whom Kafka was one. They knew nothing of Kafka during that first visit, and heard no mention of him or his work, although Das Schloss, the novel that would later lead them to be the first English-language translators of Kafka, was both started and abandoned unfinished during the period that the Muirs were involved with the Čapek brothers and their Czech culture. On the other hand, when they returned to Prague to work for the British Council immediately after the end of World War Two, the city which awaited them had itself turned into a Kafkaesque world. Muir wrote in his autobiography that he found he had returned to a city which was "the same and yet not the same, whose streets I or someone very like me had walked many years before" (Muir 1954: 255) - a perception that has something in common with Kafka's own comments about the old Jewish ghetto in Prague, although it no longer existed when he was growing up. Kafka told Gustav Janouch: "In us it still lives [...] We walk through the broad streets of the newly built town. But our steps and our glances are uncertain. [...] With our eyes open we walk through a dream: ourselves only a ghost of a vanished age" (qu. The City of K 2010: 11). Similarly, this post-war Prague seemed to both Muirs in many ways to be "a ghost of a vanished age," although in their case it was the life-giving experience of their first visit to Prague in the early 1920s, a city they had found "sizzling with hope and experiment and enthusiasm" (Muir 1968: 56), which now had been replaced by the consequences of Nazi occupation and the subsequent absorption of the Czechs into the Soviet sphere of influence - what Muir described in a letter to Stephen Spender as "a coffin of human freedom" (Muir 1974: 98).

Despite the stress and distress which this second sojourn in Prague brought personally to both Muirs, it also produced, in his Labyrinth collection of 1949, some of the best of Edwin Muir's late poetry. It could be argued that Muir's early poetry was already potentially Kafkaesque in its sense of the double-natured condition of human life and experience and its redemptive search for something that had been lost. However, working with the Kafka translations, together with his own early experiments with fiction writing in The Marionette and in the autobiographical novels The Three Brothers and Poor Tom, appears to have helped him to understand how to structure his responses to the poetic themes which forced themselves upon him. The Highland novelist Neil Gunn wrote of Muir's World War Two collection The Narrow Place that "his work [...] has caught a flame - from the fire that is burning the world" (Gunn 1943: 163); and the new thematic imagery in that wartime collection, arising out of what Muir called "the single, disunited world" (Muir 1954: 194) of Europe, continued to evolve during the poetry of his second stay in Prague immediately after the war. Increasingly in The Labyrinth, and in his next collection One Foot in Eden, we find him using Greek myth as metaphor in his poetry - for in Greek myth, as in Communism and, as Muir saw it, in Calvinism, human beings succeed or fail not in relation to their own behaviour or efforts, but because of the will of the gods who have predetermined their human lives - something that seemed especially relevant to the situation in post-war Prague. Oedipus "is made to stumble," and in the Labyrinth 
poem of that name, the eponymous speaker struggles between acceptance of his preordained fate "led by the gods," and his contrary awareness that he had "sought out his guilt" in "innocent play" (Muir 1991: 178). Greek myth is also the organising metaphor of the title poem in this Prague collection, although its presence in "The Labyrinth" is largely implicit, brought to the reader through the implications in the title itself and through a few words and phrases that contextually relate to the myth of Theseus and the Minotaur: "Since I emerged that day from the labyrinth"; "in the maze time"; "the bull [. . .] dead upon the straw" (Muir 1991: 157). An outstanding feature is the poem's long opening sentence, which Muir himself described as "deliberately labyrinthine, to give the mood" (Muir 1952). This is a sentence of thirty-five lines, the meaning of which is continually obscured and obstructed by parenthetical comments, much as Kafka's hero $\mathrm{K}$ is continually obstructed in his attempts to reach the Castle. This reminder of Kafka is continued in the imagery of "deceiving streets/That meet and part, and rooms that open/Into each other - and never a final room" (Muir 1991: 158). Other intertextual references which suggest themselves include Dostoevsky's novel The Double in which its hero Golyadkin, like Muir's Labyrinth speaker, experiences "swift recoils, so many that I almost feared/I'd meet myself returning at some smooth corner,/Myself or my ghost" (Muir 1991: 157). ${ }^{3}$

Other poems in the Labyrinth collection are more openly related to the events unfolding in Prague. In "The Usurpers," the speakers are "self-guided, self-impelled and self-sustained" and feel confident that "Our thoughts are deeds; we dare do all we think,/Since there's no one to check us, here or elsewhere"(Muir 1991: 176). The clarity of presentation in the imagiste poem "The Helmet" is terrifying in its human implications: "The helmet on his head/Has melted flesh and bone/And forged a mask instead/that always is alone" (Muir 1991: 168); while in the everyday scenario of "The Interrogation" the speakers are caught by a chance meeting with a police or government patrol (its identity is not clarified) and subjected to interrogation: "We could have crossed the road but hesitated,/And then came the patrol" (Muir 1991: 172). Muir wrote in his autobiography of Prague in this period:

The old stale fears were back. No one opened his mouth in the trams. No one said "God damn the government," knowing he would be arrested if he did. No one dared to tell what he really thought, except in his own house or to a friend he could trust. No one telephoned if he could help it, though in a very short time people knew by the slight diminution in the volume of the sound when the line was being tapped. And men at last became suspicious of their friends. (1954: 267)

${ }^{3}$ Dostoevsky became a presence in early twentieth-century Anglophone literature as a result of the translation of his fiction by Constance Garnett. In her review of Garnett's translation of The Eternal Husband in 1917, Virginia Woolf referred to Dostoevsky as "this great genius who is beginning to permeate our lives so curiously," and both she and Edwin Muir wrote of his capacity to suggest the workings of the unconscious mind in his fiction. MacDiarmid's "Letter to Dostoevsky" is an important section of his long Scots-language modernist poem A Drunk Man Looks at the Thistle (1926). 
The Irish poet Seamus Heaney wrote in the essay "The Impact of Translation," published in The Yale Review in 1987, that Edwin Muir's "two post-war volumes, The Labyrinth in 1949 and One Foot in Eden in 1956, are not like anything that was going on just then on the home poetic front"; and that his Labyrinth poem "The Interrogation" in particular "anticipates by a couple of decades the note which would be heard when A. Alvarez began to edit his influential Penguin Modern European Poets series in the late 1960s, a note as knowledgeable as it was powerless to survive with any sort of optimism in the light of what it knew." And in this, Heaney concluded, "Muir's poem is 'European"” (1987: 8-9).

Heaney's reference to the One Foot in Eden collection in his assessment of Muir's late poetry brings me to my second and contrasting consideration of Edwin Muir and Europe in this present essay: his short period in Rome as Director of the British Council Institute in the Italian city from January 1949 to July 1950. Muir had suffered a psychological collapse - what he described as "both physical and nervous exhaustion" and "a curious blind dejection for days at a time" (Muir 1974: 149) - as a consequence of the events he had witnessed and had had to deal with in Prague, and he resigned from his position as Director of the British Council Institute in July 1948. In Rome, in contrast, he was brought into direct contact with that southern sensibility he had written about so many years previously in his "North and South" Freeman article in which he had put forward his belief that "the wisdom of the South is the wisdom of adaptation, for in all terrestrial life the complete is the completely adapted" (Muir 1924: 112). Muir's first experience of Italy in the early 1920s, especially in relation to the nature of its landscape and seascape, had not been altogether a positive one. He wrote in An Autobiography:

Coming for the first time to the South, I was repelled by the violence of the colours, the sea like a solid lake of blue paint, the purple sky, the bright brown earth: to my unaccustomed eyes the contrasts seemed crude and without mystery. (Muir 1954: 210)

After Prague in the post-World War Two period, however, southern warmth was to be welcomed, and what he had earlier identified as the southern acceptance of life proved restorative to Muir the man and also inspirational to him as poet where themes of reconciliation became dominant in his work. He wrote to a friend of long standing, the poet and writer on French literature Joseph Chiari:

I'm much struck with Rome, and all its wealth of associations; you feel the gods (including the last and greatest of them) have all been here, and are still present in a sense in the places where they once were. It has brought very palpably to my mind the theme of Incarnation and I feel that probably I shall write a few poems about that high and difficult theme sometime: I hope so. Edinburgh I love, but in Edinburgh you never come upon anything that brings the thought of Incarnation to your mind, and here you do so often, and quite unexpectedly. (Muir 1974: 154-55) 
Among the poems in One Foot in Eden which develop this new theme of reconciliation, of "incarnation" in the sense, as I would understand it, of being at home with the world of the human, as opposed to pursuing the attainment of something beyond it, are Greek-myth poems such as "Orpheus's Dream," "Telemachus Remembers," "The Other Oedipus," and biblical-myth poems such as "The Annunciation," "Adam's Dream" and "One Foot in Eden," with its well-known ending: "Strange blessings never in Paradise/Fall from these beclouded skies" (Muir 1991: 213). In The Labyrinth collection, Greek myth had been used by Muir as a poetic vehicle for the presentation of human helplessness in the face of a fate over which they had no control. However, alongside that element of predetermined fate in Greek mythology, Greek myths had over the centuries also proved themselves to be stories which, like the Scottish ballads, could be endlessly told and re-told creatively, unlike the canonical and therefore less adaptable nature of biblical narratives. ${ }^{4}$ And it was this re-shaping quality that proved most significant in Muir"s use of Greek Myth in One Foot in Eden. In "Orpheus's Dream," for example, Muir takes the well-known story of Orpheus who succeeds in releasing Eurydice from the Underworld through the beauty of his music only to lose her again because he disobeys Pluto's injunction not to look upon her until both reach Earth again. Instead of following the specific detail of the original story, however, Muir's poem focuses on the power of love to overcome disaster, creating the impression of this power through the formal detail of the poem in a scenario that is left unexplained. The poem begins in media res: "And she was there [...] The foundering skiff could scarcely keep/All that felicity afloat" (Muir 1991: 200). Questions such as why a boat has been introduced into the original story (crossing the Styx, perhaps?), or who precisely its occupants are, are subordinated to the effect of the formal elements in the poem: the alliteration in the " $\mathrm{f}$ " sounds and the alternation of words with duple, single, and triple syllables which create a sense of the movement of the boat, rendered unsteady by the joy of its occupant(s) at Eurydice's appearance. Similarly, the poem's conclusion is unspecific in relation to what happens at the end of the rescue venture, but once more it is the power of love that is dominant as we see the Underworld left only with "the poor ghost of Eurydice [...] Alone in Hades' empty hall" (Muir 1991: 201). Love is dominant also in "Telemachus Remembers," where the adult son of Penelope and Ulysses at last realizes why his mother had over the years woven and unwoven her "half-finished heroes" on her web: "I wet them with my childish tears/Not knowing she wove into her fears/Pride and fidelity and love" (Muir 1991: 203). In "The Grave of Prometheus," evolutionary time has overcome the wrath of the gods at

${ }^{4}$ In a discussion of the use of Christian myth in An Essay on Criticism (1960), the critic Graham Hough comments that "those who maintain that the Christian myth is different from all others are right not because it is "truer" than any other, but because it was believed in a different way" (155-56). This, I would suggest, affects its creative use as metaphor. 
Prometheus's daring attempt to bring the gift of fire to humans, and Prometheus himself is now an integral part of the earthly world of nature:

A mineral change made cool his fiery bed,

And made his burning body a quiet mound,

And his great face a vacant ring of daisies. (Muir 1991: 200)

Although it could be argued that the use of Greek myth, both in The Labyrinth and One Foot in Eden allows Muir a greater poetic freedom and flexibility than can be found in the use of canonical biblical stories, his new creativity in the use of myth is also to be found in several of One Foot in Eden's biblical scenarios. In "Adam's Dream," for example, Muir reshapes the story of Adam's expulsion from Eden, so that the poem's focus is not on Adam's guilt or the "terror" of the symbolic "abyss" into which he has fallen, but, rather, on his acceptance of his humanity and his vision of his future descendants:

And he remembered all, Eden, the Fall,

The Promise, and his place, and took their hands, That were his hands, his and his children's hands, Cried out and was at peace, and turned again In love and grief in Eve's encircling arms. (Muir 1991: 197)

He wrote in An Autobiography that as a boy in Orkney:

I was aware of religion chiefly as the sacred Word, and the church itself, severe and decent, with its touching bareness and austerity, seemed to cut off religion from the rest of life and from all the week-day world [. . . It did not tell me by any outward sign that the Word had been made flesh [. . .] nothing told me that Christ was born in the flesh and had lived on the earth. (Muir 1954: 177-78)

In Rome, on the other hand, this image of the Word made flesh "was to be seen everywhere, not only in churches, but on the walls of houses, at cross-roads in the suburbs, in wayside shrines in the parks, and in private rooms" (Muir 1954: 278). And it was just such an image, "a little plaque on the wall of a house in the Via degli Artisti, representing the Annunciation" (Muir 1954: 278), which inspired his poem of that name. Once again, as in the "Orpheus's Dream" poem, the re-imagining of a biblical story in human terms is most successful in its lack of narrative specificity, its focus on a sense of timelessness and absorption of the two "lovers" in each other:

But through the endless afternoon

These neither speak nor movement make,

But stare into their deepening trance

As if their gaze would never break. (Muir 1991: 206) 
The collection's title-poem, "One Foot in Eden," is explicitly focused on the significance of the human world, especially in its closing stanza:

\author{
But famished field and blackened tree \\ Bear flowers in Eden never known. \\ Blossoms of grief and charity \\ Bloom in these darkened fields alone. [...] \\ Strange blessings never in Paradise \\ Fall from these beclouded skies. (Muir 1991: 213)
}

On the other hand, although Rome had a restorative effect on Muir, as man and poet he never entirely lost that northern sensibility he wrote about in his "North and South" article, a sensibility which questioned and searched after meaning in human life. Such northern themes were brought together with those of southern acceptance when he returned to Scotland in the early 1950s after the British Council decided to close its Rome Institute for reasons of economy, and both have their place in his One Foot in Eden collection, published in 1956. What one might describe as a "two cultures" poem is "The Incarnate One" where "Calvin's kirk crowning the barren brae" and "God three angry letters in a book" is contrasted with the Italian artist Giotto's religious paintings which bring together "Christ, man and creature in their inner day" (Muir 1991: 213). For the speaker in this poem, the "Mystery" given human form in a poem such as "The Annunciation," is now "impaled and bent/Into an ideological instrument" (Muir 1991: 213) such as Muir found dominant in Communism and Scottish Calvinism, and which was seen in operation in The Labyrinth in poems such as "The Usurpers" and "The Interrogation"; a dogma which could bring to human beings only "Abstract calamity, save for those who can/Build their cold empire on the abstract man" (Muir 1991: 14). Edwin Muir must have been one of the first poets to bring the theme of nuclear war into his poetry, with "The Horses" first published in the Listener in March 1955 and then placed in the second (and more questioning) section of the One Foot in Eden collection. Although there is no explicitly connected narrative in the poem, its fragmentary imagery of "the seven days war that put the world to sleep" (Muir 1991: 226) patterns in reverse form the seven days of the biblical creation myth as it brings the human technological world to silence. There is still hope in this poem, however, and the surviving humans are given a second chance to go forward to a more constructive form of life through the appearance of the "strange horses" who offer them "that long-lost archaic companionship" and a "free servitude [that] still can pierce our hearts" (Muir 1991: 226-27). In my view, this "Horses" poem makes its fullest impact when read alongside "After a Hypothetical War," published in the Listener in January 1956 (titled "The Bad Lands") and eventually included in Muir's Collected Poems of 1960 under the heading of Last Poems. Muir is not didactic in either poem, but taken together, "The Horses" and "After a Hypothetical War" put forward implicitly 
through their respective scenarios and imagery the choices open to human beings as they appeared in the dark days of "The Cold War" and the possibility of world-wide nuclear war: choices which are not irrelevant to our own time. In "After a Hypothetical War," for example, we find imagery such as : "No rule nor ruler"; "The soil on its perpetual death-bed"; "a chaotic breed of misbegotten things,/Embryos of what could never wish to be." And the poem ends: "Poor tribe so meanly cheated/Their very cradle an image of the grave./What rule of governance can save them now?" (Muir 1991: 243). One of Muir's very last poems, "The Last War," envisages what he had previously called "the articulate breath" of humanity becoming "now only the lexicon of a dream" (Muir 1991: 193, 257); while a companion poem "The Refugees born for a land unknown" seems especially prescient of the future and our present-day situation in the Middle East.

Edwin Muir was both a Scottish writer and a modernist Anglophone writer who experienced the influence of Europe at first hand as well as from his reading material, and who reflected this European influence philosophically in his poetry and in his critical and creative prose writing. And although Muir had perhaps more in his own temperament of that northern sensibility he described in his early "North and South" article as continually yearning after an ideal world beyond the present, he had also in his character and poetry a southern warmth and adaptability focused on our human world. He wrote in his autobiography of the "three mysteries" which possess human minds: "where we came from, where we are going, and, since we are not alone, but members of a countless family, how we should live with one another" (Muir 1954: 56). He saw these as "aspects of one question" (Muir 1954: 56) as opposed to separate concerns, but in his late poetry in particular it is the question of "how we should live with one another" in our present world which increasingly appears in the dominant role, and which identifies him not only as the twentieth-century European poet recognized by Seamus Heaney in his Yale Review essay, but also as a poet of continuing relevance to our own troubled twenty-first century times.

\section{REFERENCES}

Bell, Michael (1999). The Metaphysics of Modernism. In Michael Levenson, ed., 932.

Closs, August and T. Pugh Williams, eds. (1957). The Harrap Anthology of German Poetry. London: Harrap.

Duffy, Carol Ann (1994). Selected Poems. Harmondsworth: Penguin Books.

Gunn, Neil M. (1943). Books and other Things. Scots Magazine 39 (2) (May 1943): 163-64.

Heaney, Seamus (1987). The Impact of Translation. Yale Review (Autumn): 8-9. Hough, Graham (1966). An Essay in Criticism. London: Duckworth.

The City of K: Franz Kafka and Prague (2010). Prague: Franz Kafka Museum. 
Kafka, Franz (1926/1992). Das Schloss. Malcolm Pasley, ed., Frankfurt am Main: Fischer Taschenbuch Verlag.

Kafka, Franz (1930/1987). The Castle. Willa and Edwin Muir, trans., Harmondsworth: Penguin Books.

Levenson, Michael ed. (1999). The Cambridge Companion to Modernism. Cambridge: Cambridge University Press.

Muir, Edwin (1924). Latitudes. London and New York: Melrose and Huebsch.

Muir, Edwin (1927). The Marionette. London: Hogarth Press.

Muir, Edwin (1952). Chapbook. BBC Radio Scotland, 3 September.

Muir, Edwin (1954). An Autobiography. London: Hogarth Press.

Muir, Edwin (1974). Selected Letters ed. P. H., Butter. London: Hogarth Press.

Muir, Edwin (1991). Complete Poems. Peter Butter, ed., Aberdeen: Association for Scottish Literary Studies.

Muir, Willa (1968). Belonging: A Memoir. London: Hogarth Press.

Woolf, Virginia (1917). Review of Feodor Dostoevsky's The Eternal Husband. Constance Garnett, transl., Times Literary Supplement, 22 February: 91. 